\title{
LA ARMONÍA DE FACULTADES EN LA GNOSEOLOGÍA DE FRANCISCO SUÁREZ
}

\author{
JOSÉ ÁNGEL GARCÍA CUADRADO \\ Universidad de Navarra
}

\begin{abstract}
RESUMEN: El problema de la comunicación entre cuerpo y alma es un tópico de la psicología racionalista ya presente en Suárez. El Doctor Eximio critica que la imagen sea causa instrumental para producir la especie inteligible, ya que una realidad material no puede causar nada de modo eficiente en una realidad de orden superior como es el alma espiritual. Suárez examina el tipo de causalidad de las imágenes y concluye que las diversas denominaciones son inapropiadas: instrumental, material y ejemplar; esto le lleva a asumir la doctrina de la simpatía o natural armonía de las facultades propuesta por el médico Francisco Vallés. Por otro lado, subrayará el papel activo de la inteligencia; pero algunas expresiones invitan a concebir una dualidad de operaciones (sensitiva e intelectual) dando pie a admitir una armonía preestablecida o un ocasionalismo cognoscitivo. En todo caso los textos de Suárez constituyen una invitación a seguir indagando sobre la índole peculiar del pensamiento humano.
\end{abstract}

PALABRAS CLAVE: simpatía de facultades, Francisco Vallés, intelecto agente, ocasionalismo, dualismo alma-cuerpo, causalidad.

\section{The Harmony of the Faculties in the Epistemology of Francisco Suárez}

ABSTRACT: The problem of communication between the body and the soul is a topic of rationalist psychology, but is already present in Francisco Suárez. The Doctor Eximio criticizes the notion that the image is the instrumental cause, which produces the intelligible species, because a material reality cannot be the efficient cause of anything in a reality of a higher order, as is the spiritual soul. Suárez considers the types of causality that are proper to images, and concludes that the various denominations are inappropriate: instrumental, material and exemplary. This leads him to adopt the doctrine of sympathy or natural harmony of the faculties proposed by the physician Francisco Vallés. On the other hand, he underlines the active role of the intelligence, but certain expressions invite the reader to conceive a duality of operations (sensitive and intellectual), thus giving grounds to accept a pre-established harmony or cognitive occasionalism. In any case, the texts of Suárez are an invitation to continue thinking about the specific nature of human thought.

KEY WORDS: the symphatia of the faculties, Francisco Vallés, agent intellect, occasionalism, soulbody dualism, causality.

En las objeciones de Gassendi a la Sexta Meditación de Descartes, en la que trata de la distinción real entre el alma y el cuerpo, se leen una serie de preguntas que culminan así: «En una palabra: siempre queda por saber cómo lo que es corpóreo puede hacerse sentir y comunicarse con lo que no lo es, y qué proporción puede establecerse entre lo uno otro». A esta cuestión, Descartes

1 «Sed uno verbo, generalis semper difficultas manet, quomodo corporeum cum incorporeo communicare valeat, quam proportionem statuere alterius cum altero liceat». Gassendi, «Objectiones Quintae», n. 5; en Euvres de Descartes. VII, (C. Adam \& P. Tennery, eds.), Vrin, Paris, 1996, p. 345, lin. 4-6. Sigo la traducción de Vidal Peña, Meditaciones metafísicas con objeciones y respuestas, Alfaguara, Madrid, 1977, pp. 274-275. 
no da respuesta alguna². Y, ciertamente, desde su concepción del alma y del cuerpo es difícil poder conciliar esas dos realidades: «el espíritu es concebido como una cosa subsistente, aunque no se le atribuya nada de lo que pertenece al cuerpo, y, al mismo tiempo, que el cuerpo es concebido como una cosa subsistente, aunque no se le atribuya nada de lo que pertenece al espíritu» ${ }^{3}$. En definitiva, manteniendo la espiritualidad del alma, Descartes no acierta a determinar cómo se comunican la sustancia material y la espiritual ${ }^{4}$. El silencio de Descartes deja abierta la cuestión para que sus discípulos ensayen diversas explicaciones a la interacción de cuerpo y mente. Así por ejemplo, el filósofo cartesiano Arnold Geulincx (1625-1669) mantendrá una teoría ocasionalista según la cual no existe una interacción causal real entre cuerpo y espíritu, sino una acción divina. Por ejemplo, con ocasión de un acto de mi voluntad, Dios moverá mi brazo. Algunos textos de Descartes dan pie a esta interpretación ${ }^{5}$. De esta manera se abre la puerta al dualismo antropológico y al ocasionalismo ontológico como la única explicación válida a la mutua influencia entre la res extensa y la res cogitans.

Descartes y sus discípulos llevan hasta sus últimas consecuencias unos presupuestos heredados de la escolástica barroca. Más concretamente, la influencia de Francisco Suárez parece evidente en el planteamiento de esta cuestión ${ }^{6}$. Lo cierto es que Suárez ya formuló en términos precisos el problema y ensaya una solución mediante la doctrina de la concomitancia y simpatía de las potencias. En efecto, en su tratado sobre los ángeles afirma: «Una cosa material no puede actuar sobre el espíritu, porque no existe proporción con él, la cual es necesaria entre el agente y el paciente. Y por la misma razón un objeto material no puede producir una forma espiritual por su virtud natural, porque está en un orden completamente inferior ${ }^{7}$. A este propósito cita el modo en que el

2 Cf. Pereira, J. (ed), Suárez. Between Scholasticism and Modernity, Marquette University Press, Milwaukee, 2006, p. 236.

3 «Mentem ut rem subsistentem intelligi, quamvis nihil plane illi tribuatur quod pertineat ad corpus, \& vice versa etiam Corpus intelligi ut rem subsistentem, etsi nihil illi tribuatur quod pertineat ad mentem». R. Descartes, "Quartae Responsiones», en Euvres de Descartes. VII, p. 226, lin. 10-13. (traducción Vidal Peña, p. 184).

4 Cf. Pereira, J.(ed), Suárez. Between Scholasticism and Modernity, pp. 218-219.

5 Ibidem.

6 El problema de la inmortalidad del alma en Descartes sería incomprensible sin la tradición escolástica. Cf. Gilson, É., Index scolastico-cartésien, Vrin, Paris, 1979, pp. i-vi; 369370; Courtine, J. F., «Descartes et la Scolastique tardive», en Lire Descartes aujord'hui, (O. Depré-D. Lories, eds.), Éditions Peeters, Louvain, 1997, pp. 1-20.

7 «[... $]$ res materialis non potest agere in spiritum, quia non habet cum illo proportionem, quam inter agens et patiens necessaria est. Et eadem ratione non potest materiale obiectum spiritualem formam producere virtute naturali, quia est omnino inferioris ordinis». SuÁrez, F., De angelis Lib. II, cap. 6, n. 10, en Opera omnia (II), Ludovicus Vivès, Paris, 1856, p. 128. 
hombre es capaz de formar la especie inteligible casi por excitación u ocasión de la presencia del objeto ${ }^{8}$.

¿Cómo salvar entonces la distancia entre lo material y lo espiritual? Descartes tendrá que recurrir a un dudoso expediente: la glándula pineal, un órgano del cerebro donde se efectúa la comunicación entre lo material y lo espiritual. Suárez, por el contrario, intenta resolver los inconvenientes del dualismo mediante el recurso a la simpatía de las potencias, una doctrina seguida por los médicos renacentistas ${ }^{9}$. Veamos con más detalle el contexto de las afirmaciones del Doctor Eximio.

\section{La PRODUCCIÓN DE LA ESPECIE INTELIGIBLE EN EL COMENTARIO AL DE ANIMA}

En la gnoseología escolástica de cuño aristotélico se postula la existencia de una entidad mediadora entre el conocimiento intelectual —abstracto y universal - y la realidad particular percibida por los sentidos. La species inteligibilis es la instancia psicológica que sin existir como tal en la realidad material permite el conocimiento intelectual de la misma ${ }^{10}$. Conocer intelectualmente no es una actividad productora (poiesis) pero se precisa la «producción» de la especie inteligible para llegar de hecho a «inteligir». Conocer inteligiblemente es poseer intencionalmente la realidad, esto es, poseer en la inteligencia la representación intencional de lo real sin lo particular sensible. Esa «intención» no está dada de entrada en la realidad y por eso el entendimiento humano debe "producirla». La inteligencia humana, por tanto, tiene una cierta pasividad por lo que tiene de recepción de la especie inteligible en el intelecto paciente; pero en cuanto que el intelecto agente "produce» la especie inteligible, el conocer es actividad y no sólo "un cierto padecer» ${ }^{11}$.

En gran parte de la tradición aristotélica la producción de las especies es un caso más de la producción en el mundo natural y debería explicarse mediante la clásica tipología de la causalidad. La causa final es el inteligir mismo; la causa formal sería la misma especie inteligible en cuanto representación intencional de la forma conocida. Por su parte, la causalidad eficiente o agente puede

8 «[...] dicatur autem illam ab obiecto accipere, quia non nisi in praesentia illius, et quasi per excitationem, vel occasionem eius illam in se format». Ibidem.

9 La influencia de Hieronimus Fracastorius (1483-1553) en Descartes y la de Francisco Vallés (1524-1592) en Suárez ha sido estudiada con detalle por AmaraL, P., «Harmony in Descartes and the Medical Philosophers», en Philosophy Research Archives 13 (1987-1988), pp. 499-556.

10 Un completo tratamiento desde el punto de vista histórico se encuentra en L. Spruit, Species inteligibilis, from perception to knowledge, (2 vols.), BRILL, E. J., Leiden, 1994-1995.

11 Un tratamiento de la causalidad de la especie inteligible ya constituida como tal en el acto de la intelección puede hallarse en González Ayesta, C., «Sobre el escotismo de Suárez: el caso de la causalidad de la especie», en La causalidad en la filosofía moderna, EchavarRía, A. \& FrancK, J. F. (eds.), Servicio de Publicaciones, Universidad de Navarra, Pamplona, 2012, pp. 9-16. 
ser principal —el intelecto agente—e instrumental —las imágenes sensibles—. Finalmente, la causa material estaría constituida por las imágenes sensibles a partir de las cuales se configuran las especies inteligibles ${ }^{12}$. El problema principal de esta explicación se encuentra en la relación entre la causalidad eficiente —de índole espiritual (el intelecto agente) — y el instrumento material (las imágenes sensibles). ¿En qué sentido el agente espiritual puede verse afectado por lo material? o ¿cómo puede el agente espiritual servirse de lo material para consumar una entidad espiritual?

Suárez conocía de primera mano la tradición psicológica de Aristóteles, pues no en vano había explicado el De anima en Segovia. Es lógico pensar que el Eximio se sirviera de las interpretaciones más comunes que circulaban por la Universidad de Salamanca para sus explicaciones académicas ${ }^{13}$. Pero la cuestión de la causalidad en la producción de la especie inteligible distaba mucho de ser una cuestión pacíficamente aceptada entre los escolásticos salmantinos.

Cuando Suárez trata del conocimiento intelectual en su comentario al De anima reconoce la necesidad de la imagen junto al intelecto agente en la intelección: «No hay duda de que no solamente se requiere de ella [de la acción del entendimiento agente], sino también de la imagen que se da en el sentido interno y que de alguna manera concurre a la producción de la especie inteligible. En efecto, si esa capacidad espiritual la produjera sin depender de la imagen, podría también desde el principio producir las especies de todas las cosas, y no tendría en este punto dependencia del sentido; pero la experiencia demuestra lo contrario» ${ }^{14}$. Sin embargo, Suárez discrepa de la tradición tomista en el valor instrumental de las imágenes en orden a la intelección. Las objeciones que plantea el Eximio a esta tesis son las siguientes:

1. La imagen es de orden inferior (material) y por ello no puede intervenir por su propia naturaleza para producir un efecto de orden superior (espiritual) como es la especie inteligible ${ }^{15}$.

2. Por otro lado, el Eximio se pregunta si la imagen sensible recibe algo de la acción del intelecto agente. Si nada recibe, nada cambia en su naturaleza

12 Un tratamiento histórico del problema de la causalidad de las imágenes se encuentra en Ercilla, J., De la imagen a la idea, Gredos, Madrid, 1959.

13 Suárez recibió su primera formación filosófica en la Facultad de Artes de Salamanca donde asistió a las lecciones del dominico Mancio del Corpus Christi. Cf. ScorRaILle, R. de, Francisco Suárez, Subirana, Barcelona, 1917, pp. 53-93.

14 «Constat enim non solam illam, sed etiam phantasma, in sensu interiori existens, esse necessarium, et aliquo modo concurrere ad productionem speciei intelligibilis, nam si illa virtus spiritualis id posset sine dependentia a phantasmate, simul et a principio posset efficere species omnium rerum, neque in ea re haberet dependentiam a sensu, cuius contrarium experientia demonstrat». SuÁRez, F., Commentaria De anima, Disp. IX, q. 2, n. 4. Sigo la edición crítica y traducción castellana de S. Castellote (ed.), Francisco Suárez. De anima. Tomo 3, Fundación Xavier Zubiri, Madrid, 1991, p. 82.

15 «Est enim contra illam ratio communis; quod instrumentum inferioris ordinis non potest naturaliter concurrere ad producendum effectum superioris ordinis, maxime tam superioris quantum est res spiritualis supra materialem». SuÁrez, F., Commentaria De anima, Disp. IX, q. 2, n. 8, p. 88. 
material; si recibe algo, lo recibido debe ser espiritual, pero entonces se puede objetar que nada material — la imagen sensible — es capaz recibir una entidad espiritual. Por el contrario, si se responde que lo recibido es algo material, no logramos salir del ámbito de lo meramente sensible y material. Así pues, parece que el intelecto agente no actúa realmente sobre la imagen. Sólo es posible un cierto contacto virtual entre la imagen y el intelecto agente proveniente de la común radicación en la misma alma ${ }^{16}$; pero entonces no sería necesario recurrir al intelecto agente ${ }^{17}$.

3. En definitiva, «el recto orden de la naturaleza exige que para producir una cosa de un determinado orden se designe una capacidad del mismo orden o superior. Luego es contrariar el orden de la naturaleza pretender valerse de una cosa material para producir una cosa espiritual» ${ }^{18}$.

De esta manera, el Eximio cierra el camino para que la imagen pueda ser considerada instrumento material, pues para serlo tendría que recibir de modo transitorio, verdadero e intrínseco la virtud del agente principal en orden a realizar la operación como con-causa. En consecuencia, el salto de lo sensible a lo espiritual no puede provenir de ninguna trasmutación ontológica en el modo de ser de la imagen, puesto que el entendimiento agente no actúa realmente sobre la imagen.

Una vez criticada la tesis de la causalidad instrumental, el jesuita granadino presenta una objeción a su propia postura proveniente de la tradición tomista, según la cual «en la especie inteligible se dan dos aspectos: el ser una entidad espiritual y el ser representativa. Ambos son reales y ambos han de tener una causa eficiente. Ahora bien, el entendimiento agente puede por su propia virtud

16 «Quid addatur phantasmati ex illa unione ad intellectum agentem? Si nihil addatur, non plus potest quam antea. Si additur, vel est spirituale, et hoc non, quia spirituale non potest recipi in materiali, vel est materiale et redit eadem difficultas. Praeterea, inter phantasma et intellectum agentem non potest fingi alia unio, nisi quod radicantur in eadem anima et eodem supposito tamquam instrumenta illius. Quod quidem Capreolus et Ferrariensis, supra, coacti concedunt, nam illud quod dicitur uniri intellectum agentem phantasmati per assistentiam et contactum virtualem verba tantum sunt, et iure nullam aliam unionem concipit intellectus praeter dictam; illa autem non est sufficiens, nam ex ea nulla virtus phantasmati accrescit». Ibíd., pp. 88-90.

17 «Item, similiter dici potest quod phantasma eo ipso quod est radicatum in anima spirituali est potens in virtute illius ad causandam speciem in intellectu: ergo non est necessarius intellectus agens. Patet consequentia, nam sicut alii asserunt intellectum agentem uti phantasmate tamquam instrumento, et phantasma id posse in virtute intellectus agentis, ita et facilius dici posset phantasma in virtute animae spiritualis id posse». Ibídem. Suárez alude a la doctrina de Silvestre de Ferrara: en su planteamiento no hay necesidad del intelecto agente para elevar la imagen sensible al nivel de inmaterialidad propio del inteligir.

18 «Ultimo arguitur, quia rectus ordo naturae postulat ut ad productionem rei alicuius ordinis destinetur virtus eiusdem vel superioris ordinis; ergo contra ordinem naturae est dicere rem materialem assumi ad efficiendam rem spiritualem». El texto continúa así: «Et confirmatur, nam multo difficilius est quod anima efficiat rem spiritualem, mediante materiali, quam quod efficiat illam mediante sola virtute spirituali; ergo ipsa naturae dispositio postulat ut fiat isto faciliori modo, et non alio superante ordinem naturae». Ibídem. 
producir la entidad espiritual, pero no la entidad de esta o aquella representación; para esto se precisa el acto de la fantasía como causa parcial que produzca en la especie la representación, en la cual no hay supremacía de la especie sobre él» ${ }^{19}$. El Doctor Eximio niega la validez de esta objeción ya que la imagen no puede producir eficientemente nada en la especie - ni total ni parcialmente-, porque o bien sería la propia imagen la que produciría algo por su propia virtud, o bien sería en virtud del intelecto agente. La imagen no puede producir eficientemente la especie inteligible por sí misma, porque es imposible que una cosa material produzca a sus propias expensas una realidad espiritual. Y tampoco la imagen puede actuar en virtud del entendimiento agente, porque la unión de la imagen con el intelecto agente no confiere nada a la imagen, como ya se $\operatorname{dijo}^{20}$.

El Eximio apunta que incluso para muchos tomistas la imagen no posee ninguna eficiencia - ni siquiera instrumental — en orden a la producción de la especie inteligible, y por tanto cabría asignar a las imágenes una causalidad meramente material ${ }^{21}$. Pero esta propuesta tampoco parece aceptable para el teólogo granadino por razones similares por las que se desechó la causa instrumental de la imagen: «[...] esto es imposible: 1. Porque la especie espiritual no puede ser educida de la potencia del sujeto material; 2 . Porque la forma no se educe más que de la potencia del sujeto en la que se recibe; pero la especie inteligible no es recibida en la imagen, sino en el intelecto posible; luego se educe de la potencia de ese intelecto y no de las imágenes. Ni tampoco se dice que la imagen concurre materialmente, ya sea la propia materia sobre la cual opera el intelecto agente, ya sea que el agente opere acerca del sujeto en que es recibida su acción; pero la acción del intelecto agente es recibida en el posible,

19 «Sed ad haec dicunt quidam quod in specie intelligibili duo sunt, nempe esse entitatem spiritualem et esse repraesentativam, et utrumque est reale et utriusque debet dari causa efficiens; intellectus autem agens potest ex propriis efficere entitatem spiritualem, non tamen huius vel illius repraesentationis, et ad hoc requiritur phantasma ut partiale efficiens, efficiens in specie repraesentationem in qua non superatur ab illa». Y a continuación añade que esta doctrina se encuentra en Tomás de Aquino: «Et hoc insinuat D. Thomas, De veritate, q. 10, a. 6, ad 7, ubi ait quod effectus, vel species intelligibilis, relinquitur in intellectu possibili secundum conditiones utriusque, id est, intellectus agentis et phantasmatis, nam phantasma, inquit, facit ut species sit rei determinatae». SuÁrez, F., Commentaria De anima, Disp. IX, q. 2, n. 9, pp. 90-92.

20 «[...] quidquid est in specie intelligibili est spirituale, etiam ipsa repraesentatio, quae necessario debet altiori modo fieri quam phantasma; ergo impossibile est quod phantasma effective efficiat aliquid in specie nec partialiter nec totaliter. Probo consequentiam, nam vel hanc partialem actionem habet phantasma propria virtute, aut in virtute intellectus agentis. Non primum, quia impossibile est quod res materialis ex propriis efficiat aliquo modo rem spiritualem educendo illam de potentia subiecti spiritualis». SuÁrez, F., Commentaria De anima, Disp. IX, q. 2, n. 9, p. 92.

21 «Propter haec ergo argumenta alii etiam ex Thomistis aiunt phantasma non concurrere effective, sed materialiter ad productionem specierum, solum autem intellectum agentem illam efficere. Quod non sic intelligunt quasi ipsum phantasma sit materia ex qua educitur species intelligibilis». SuÁrez, F., Commentaria De anima, Disp. IX, q. 2, n. 10, p. 94. 
no en las imágenes. Se dice, por tanto, que la imagen concurre materialmente, porque como si ofreciera la materia al intelecto agente para hacer las especies inteligibles. Esta opinión, rectamente explicada parece en esta parte la más probable ${ }^{22}$.

El texto suareciano diferencia implícitamente dos sentidos de la causalidad material. Por una parte tenemos la causa material in qua, esto es, donde se introduce la forma. Y en este sentido, la especie inteligible no se puede encontrar en nada material, y por esta razón la imagen no puede ser causa material de la especie. Más bien la especie inteligible se inscribe «en» el intelecto posible, y por eso cabe atribuirle a ese intelecto la causalidad material in qua. Cabe hablar también de una causa material ex qua, es decir, aquel principio del que se sirve el intelecto agente para sacar o extraer la representación inteligible: pero igualmente es imposible que de una realidad material se extraiga una realidad espiritual; luego tampoco en ese sentido cabe calificar a la imagen como causa material ex qua de la especie inteligible. Suárez habla también de una causalidad material circa quam ${ }^{23}$, que sería el objeto sobre el cual actúa el intelecto agente para imprimir en el posible la especie inteligible. Pero en este sentido, la imagen tampoco ejerce causalidad material alguna, sino más bien una causalidad de tipo ejemplar ${ }^{24}$.

Con todo, el Eximio reconoce que la imagen proporciona una cierta «materia» para la producción de la especie inteligible, siempre que se reconozca que se trata de una expresión imperfecta e impropia ${ }^{25}$. Como es posible advertir, el

22 «Id enim impossibile est: $1^{\circ}$, Quia species spiritualis non posset educi de potentia subiecti materialis. $2^{\circ}$, Quia forma non educitur nisi ex potentia subiecti in quo recipitur; species autem intelligibilis non recipitur in phantasmate, sed in intellectu possibili; ergo de potentia huius intellectus educitur, non phantasmatis. Nec etiam dicitur phantasma materialiter concurrere, quia sit propria materia circa quam operatur intellectus agens, quia agens operatur circa subiectum in quo recipitur eius actio; actio autem intellectus agentis recipitur in possibili, non in phantasmate; dicitur ergo phantasma materialiter concurrere, quia quasi praebet materiam intellectui agenti ad efficiendas species intelligibiles. Quae opinio recte explicata videtur in hac parte probabilior». SuÁrez, F., Commentaria De anima, Disp. IX, q. 2 , n. 10 , p. 94.

23 La distinción entre materia in qua, ex qua y circa quam se encuentra en Disputaciones metafísicas, Disp. XIII, Sec. I, n. 1. Cf. Disputaciones metafísicas. III, RáBADE, S. (ed.), Gredos, Madrid, 1961, pp. 384-385.

24 «Nec etiam dicitur phantasma materialiter concurrere, quia sit propria materia circa quam operatur intellectus agens, quia agens operatur circa subiectum in quo recipitur eius actio; actio autem intellectus agentis recipitur in possibili, non in phantasmate». SuÁREz, F., Commentaria De anima, Disp. IX, q. 2, n. 10, p. 94. Sin embargo, Fernández Burillo apunta en Suárez a un tipo de causalidad material circa quam para subrayar el papel activo del intelecto: "Conocer será actividad, espontaneidad, en presencia del objeto (circa obiectum) y en referencia a él. Por eso la sensibilidad no es causa material, ex qua, sino circa quam; el fantasma no es causa instrumental, sino objeto con ocasión y en presencia del cual se abstrae. No se abstrae de él, sino en presencia de él». FERnández Burillo, S., "Introducción a la teoría del conocimiento de Francisco Suárez», en Pensamiento 48 (1992), p. 226.

25 Así se emplea, por ejemplo en SuÁRez, F., Commentaria De anima, Disp. IX, q. 2, n. 10, p. 94. 
sentido de ese concurso material ha llegado a ser bastante confuso entre los comentadores de Aristóteles. En efecto, concurso material de la imagen no quiere decir que ella sea la materia en la que se plasma la especie inteligible (materia in qua), pues sólo el intelecto posible es el receptor de la especie; ni tampoco de la imagen sensible se puede educir la especie inteligible (materia ex qua) pues nada espiritual puede salir de lo material; ni tampoco la imagen puede ser la materia sobre la cual actúa el intelecto agente (materia circa quam), pues el intelecto agente no añade nada a la imagen como antes afirmamos.

El problema que late en toda la exposición suareciana es el de la imposibilidad de que un principio material influya en una realidad espiritual. En palabras del Eximio: «ningún sujeto activo puede sobrepasar en su modo de actuar su modo de ser. Luego la cosa material, que es extensa en su modo de ser, con dependencia del sujeto cuanto, con mucha más razón mantendrá esa dependencia en su actividad $»^{26}$. Estas últimas palabras nos pueden dar una clave para entender la renuencia de Suárez a aceptar la imagen como causa material e instrumental de la intelección. Parece que la causalidad material connota la misma realidad material — con extensión y cantidad- que de ningún modo puede entrar esencialmente en el acto de intelección. Consiguientemente, siendo el inteligir una operación espiritual no puede encontrarse nada de materialidad pues de este modo se comprometería no sólo la espiritualidad de la inteligencia, sino también la misma inmortalidad del alma ${ }^{27}$. Para evitar todo naturalismo en el conocer, Suárez pretende alejar la materia del acto intelectivo, sin otorgarle ninguna influencia real en el conocer intelectual ${ }^{28}$.

\section{Hacia una nUeva tipología de la CAUSALIdad}

Las imágenes de la fantasía son necesarias para la producción de la especie inteligible, pero no participan como causa eficiente, ni instrumental, ni tampoco propiamente material. Entonces ¿de qué tipo de participación es posible hablar aquí? En la propuesta suareciana aparecen las vacilaciones terminológicas

26 «Nullum enim agens potest transcendere in modo suae actionis modum sui esse; ergo res materialis, quae in modo essendi est extensa, pendens a subiecto quanto, multo magis id habebit in actione sua». Suárez, F., Commentaria De anima, Disp. IX, q. 2, n. 9, p. 92. "Sujeto cuanto»: así lo traducen los editores: el sentido es «el sujeto afectado ya por el accidente cantidad», o «determinado por la cantidad».

27 Cf. Roubinet, P., «Immaterialité de l'intelect et immortalité de l'âme humaine selon Francisco Suárez», en Cuadernos Salmantinos de filosofía 1 (1980), pp. 280-282; D. Des Chene, «La inmmaterialité de l'âme: Suárez et Descartes», en Descartes et le Moyen Age, Vrin, Paris, 1997, pp. 319-327.

${ }_{28}$ No podemos entrar a analizar la concepción suareciana de la materia. Me remito a los trabajos de Sреснт, R., "Aspects "cartesians", de la théorie suarezienne de matière», en Lire Descartes aujourd'hui, (Depré, O.-Lories, D., eds.), Editions Peeters, Louvain, 1997, pp. 21-45, y Rinaldi, T., «Il problema delle species conoscitive nel De anima di Suárez», en La filosofia del Siglo de Oro, (Lamacchia, A., ed.), Levante Editori, Bari, 1995, pp. 429-464. 
propias de un filósofo original que pugna con los conceptos acuñados por la tradición que no acaban de ser cauce adecuado de su propio pensamiento. De este modo, en su comentario al De anima parece oscilar entre desechar el concurso instrumental de la imagen o aceptar esa denominación mostrando su impropiedad.

En efecto, en mitad de esta lucha por hallar los términos precisos, Suárez se esfuerza por no romper completamente los lazos que le unen a la tradición tomista. Así, cuando Suárez niega la causalidad instrumental de las imágenes, él mismo trae a consideración los textos donde Tomás de Aquino, de modo expreso afirma tal causalidad ${ }^{29}$. La respuesta de Suárez es escueta, acudiendo de nuevo a la impropiedad del lenguaje: «[Santo Tomás] habla en sentido amplio de la esencia del instrumento. Como el acto de la fantasía concurre en alguna medida a la determinación del entendimiento agente, por eso se dice que lo pone en movimiento o que es su instrumento, pero remotamente y no en un sentido muy propio ${ }^{30}$. Así pues, Suárez parece admitir la calificación de causa instrumental aplicada a la imagen sensible, siempre que se reconozca la impropiedad de este modo de hablar.

De modo similar, cuando Suárez acepta denominar a la imagen «causa material», no deja de advertir la impropiedad de esas palabras hasta acabar acuñando los términos quasi materia y quasi exemplar, como si fueran intercambiables entre sí. Si la función de la imagen es meramente la de determinar al entendimiento agente en la producción de esta especie o aquella no puede ser propiamente una materia de la que se extrae la especie inteligible, sino más bien un modelo del que se sirve el intelecto agente para "pintar» una determinada representación intencional en el intelecto posible: «Esta determinación no se realiza por una eficiencia de la imagen misma, sino suministrando meramente al entendimiento agente la materia y el ejemplar, por así decir, y esto en razón de la unión que tiene lugar en una misma alma» ${ }^{31}$. Poco después intenta aclarar un poco más su propuesta: «En esta línea pienso, por tanto, que el entendimiento posible está desnudo de todas las especies, pero que el alma tiene capacidad de producir en el entendimiento posible las especies de las cosas que el sentido conoce, no porque el mismo conocimiento sensible concurra eficientemente a esa actividad, sino porque posee la materia, por así decir, o porque actúa a manera de estimulante del alma o a manera de ejemplar. Y así resulta

29 Tomás de Aquino, Summa theologiae I, q. 85, a. 1, ad 3; q. 84, a. 6, ad 1; Contra Gentes, c. 77 ; De veritate q. 10, a. 6, ad 7. En éste último afirma expresamente que el acto de la fantasía es instrumento para la producción de las especies, como el mismo Suárez reconoce.

30 «[D. Thomae] loquitur late de ratione instrumenti, nam quia phantasma aliquo modo concurrit ut determinet intellectum agentem, ideo dicitur movere vel esse instrumentum remote tamen et non adeo proprie». SuÁREz, F. , Commentaria De anima, Disp. IX, q. 2, n. 13, p. 98.

31 «Haec determinatio non fit per efficientiam aliquam ipsius phantasmatis, sed per hoc solum quod materiam praebet et quasi exemplar intellectui agenti, idque propter unionem quam habet in eadem anima». Suárez, F., Commentaria De anima, Disp. IX, q. 2, n. 12, p. 94. Esta última acotación nos introducirá en la doctrina de la simpatía de facultades. 
que tan pronto como el alma conoce algo por medio de la fantasía, lo pinta, por así decir, en el entendimiento posible por medio de su capacidad espiritual $\aleph^{32}$.

En última instancia, Suárez parece reducir la materia a causalidad ejemplar ${ }^{33}$ evidenciando de este modo el influjo del ejemplarismo agustiniano y neoplatónico en su propia gnoseología ${ }^{34}$. Así pues, el entendimiento agente imprime (espiritualmente) la forma en el entendimiento posible «mirando» como modelo las formas sensibles suministradas por la imaginación. De este modo se evita que su materialidad enturbie la espiritualidad de la inteligencia. El precio a pagar es que la imagen sensible permanece de algún modo «fuera» de la misma intelección, como una realidad extrínseca a la especie inteligible producida por el intelecto agente. En efecto, la causa ejemplar viene a ser en realidad una causa formal extrínseca ${ }^{35}$ y por consiguiente afectará sólo extrínsecamente a la acción del agente. Pero por otra parte, la causalidad ejemplar posee todavía una cierta eficiencia sobre el intelecto agente, y por eso no puede ser en sentido estricto una causa ejemplar ${ }^{36}$.

En todo caso, es notorio el esfuerzo de Suárez por encontrar una nueva terminología a este tipo de causalidad: causa quasi material, quasi exemplar o ad instar exemplaris ${ }^{37}$. Estas denominaciones manifiestan ya la inadecuación de las categorías clásicas para explicar el conocimiento humano, pero Suárez todavía no está en condiciones de ofrecer una nueva conceptualización, dejando así espacio a la ambigüedad.

32 «Ad hunc ergo modum arbitror intellectum possibilem de se esse nudum speciebus, habere tamen animam virtutem spiritualem ad efficiendas species earum rerum, quas sensus cognoscit, in intellectu possibili, ipsa imaginatione sensibili non concurrente effective ad eam actionem, sed habente se quasi materia, aut per modum excitantis animam, aut sane per modum exemplaris. Et ita fit quod statim ac anima per phantasiam cognoscit aliquid, per virtutem suam spiritualem quasi depingit rem illam in intellectu possibili». SuÁREz, F., Commentaria De anima, Disp. IX, q. 9, n. 12, p. 96.

33 Cf. ERcilla, J. De, De la imagen a la idea. Estudio crítico del pensamiento tomista, Gredos, Madrid, 1959, p. 304. Sin embargo, en el planteamiento suareciano la causalidad ejemplar acabará siendo absorbida por la causalidad eficiente, la única que cumple todas las condiciones para ser considerada verdaderamente como causa. Cf. OtIvo, G., «L'efficience en cause: Suárez, Descartes et la question de la causalité», en Descartes et le Moyen Age, (BIARD, J.-RASHED, R., eds.), Vrin, Paris, 1997, pp. 94-102.

34 Spruit, L., Species Intelligibilis (II), p. 304.

35 Así lo reconoce Dunne cuando afirma que la imagen es una «causa formal extrínseca», a modo de ejemplar a cuya semejanza se forma la especie inteligible en el intelecto posible. Cf. Dunne, P., «The Production of the Intelligible Species», The New Scholasticism, 27 (1953), pp. 194-197.

36 "The phantasm is not an actual exemplar because it cannot be an exemplary cause (which is a species of efficient cause)». P. Amaral, «Harmony in Descartes and the Medical Philosophers", p. 538.

37 Así se lee en la edición de Baltasar Álvarez: quasi exemplar y ad instar exemplaris. Cf. SuÁrez, F. , Tractatus de anima. Commentaria Summa theologica, en Opera omnia (III), Apud Ludovicum Vives, Paris 1861, Lib. IV, cap. 2, n. 12, p. 719. 
Al hilo de los textos suarecianos, Castellote añade nuevas denominaciones a este tipo de causalidad atribuida a las imágenes sensibles: causa excitativa, causa determinativa, y causa exigitiva ${ }^{38}$.

1. La imagen sensible actúa como «excitante» de la facultad del alma en orden a la operación, y por eso podría denominarse causa excitativa. Esta denominación no deja de ser problemática, pues si la imagen sensible actúa como excitante del alma volvemos al problema de cómo un agente material puede actuar sobre una realidad espiritual. De nuevo, Suárez debe admitir implícitamente que hablar de «excitante del alma» es sólo un modo impropio de hablar: «el conocimiento sensible [...] actúa a manera de estimulante del alma o a manera de ejemplar» ${ }^{39}$. Estas ambiguas expresiones no terminan de aclarar si lo material influye de algún modo sobre lo espiritual. Para salvar la cuestión podría distinguirse entre el ejercicio de una potencia y su especificación: el intelecto agente permanece indiferente con respecto a la imagen en su ejercicio, pero en cuanto a su determinación requiere ser «excitada» por la imagen. Pero así tampoco parecen resolverse los problemas: «En cuanto al ejercicio mismo, es decir, el que la actividad de la imaginación sea un excitante del alma en cuanto al ejercicio de la operación intelectual, esto mismo conviene someterlo a crítica, en la posición de Suárez. ¿Qué quiere decir, en efecto, que el fantasma se comporta como excitantis animam?» ${ }^{40}$. Este mismo autor apunta a una posible interpretación de esta paradoja negando que la imagen mueva causalmente al entendimiento agente, considerando que la imagen sea un ejemplar pasivo, es decir que sea «un excitante que excita sin excitarse ${ }^{41}$. Pero en realidad de este modo lo que se afirma es que «según Suárez, el fantasma no es más que una condición para que el entendimiento agente tome una dirección determinada a su presencia $»^{42}$.

2. La imagen es causa determinativa del intelecto, en el sentido de que la única función de la imagen es determinar al entendimiento agente (indeterminado de suyo) en la producción de esta o aquella especie determinada. Como apuntábamos con anterioridad, se trata en realidad de un modelo o ejemplar del que se sirve el intelecto agente para «pintar» una determinada representación intencional en el intelecto posible. Castellote la llama «causa determinativa» porque el Eximio había afirmado que «el entendimiento

38 Cf. Castellote, S., "La teoría suareciana de las causas desde el punto de vista del Agathón», en Francisco Suárez. "Der ist der Mann». Homenaje al Prof. Salvador Castellote, Facultad de Teología San Vicente Ferrer, Series Valentina, L, Valencia, 2004, pp. 67-68.

39 "Ad hunc ergo modum arbitror intellectum possibilem de se esse nudum speciebus, habere tamen animam virtutem spiritualem ad efficiendas species earum rerum, quas sensus cognoscit, in intellectu possibili, ipsa imaginatione sensibili non concurrente effective ad eam actionem, sed habente se quasi materia, aut per modum excitantis animam, aut sane per modum exemplaris». Suárez, F., Commentaria De anima, Disp. IX, q. 2, n. 12, p. 96. La cursiva es mía.

40 Ercilla, J. DE, De la imagen a la idea, p. 301.

$41 \quad$ Ibíd., p. 305.

42 Ibidem. La cursiva es del original. 
agente nunca produce especies, si no está determinado por el conocimiento de la fantasía ${ }^{43}$. En diversas ocasiones Suárez apunta a ese papel de la imagen para la determinación de la especie, puesto que el intelecto agente es indiferente a la producción de estas especies determinadas, y requiere la determinación propia de la fantasía ${ }^{44}$.

3. La necesidad de la imagen sensible para la determinación de la especie lleva a Castellote a hablar de un nuevo tipo de causalidad: la causa exigitiva. En efecto, en el estado actual, es decir, el alma unida al cuerpo, no sólo se requiere la fantasía como excitante del alma, sino también se exige la intervención de la imagen para pensar mediante la conversión a las imágenes: «el alma se vuelve hacia las cosas conociéndolas y amándolas, no de otro modo; este volverse, por tanto, exige especies en el entendimiento ${ }^{45}$. En efecto, «en el cuerpo conoce mediante un volverse hacia el fantasma sensible» ${ }^{46}$.

Reconociendo el sentido con el que Castellote propone estos nuevos tipos de causalidad, hemos de reconocer que el Eximio no emplea esta terminología para referirse a las imágenes. Es cierto que la imagen es de algún modo un cierto excitante del alma, y una cierta determinación, o incluso una condición necesaria exigida para la intelección. Pero parece que Suárez tiene especial cuidado en emplear el término "causa» aplicado a la imagen, incluso en estos sentidos derivados.

En realidad todas estas denominaciones anteriormente citadas están relacionadas entre sí. Suárez se refiere a ellas de manera como si fueran casi sinónimas. Apuntan a diversos aspectos de cómo la imagen sensible interviene en la producción de la especie inteligible. Pero a pesar del esfuerzo denodado del Doctor Eximio, la cuestión de cómo salvar la espiritualidad de la mente en la materialidad de lo sensible permanece irresuelta. Por una parte, los dos ámbitos (lo espiritual y lo material) no deben interferir entre sí para no enturbiar la espiritualidad de la operación de entender; por otro lado, de algún modo esos ámbitos deben conectarse entre sí para que el hombre conozca, de hecho, lo real. ¿Cómo reducir a una unidad dos principios que deben ser irreductibles entre sí? El problema de la conexión entre la res extensa y la res cogitans propio de la filosofía racionalista se encuentra aquí planteado con toda claridad.

43 «Intellectus agens numquam efficit species nisi a phantasiae cognitionem determinetur». Suárez, F., Commentaria De Anima, Disp. IX, q. 2, n. 11, p. 94. La cursiva es mía.

${ }^{4}$ «Quia intellectus agens efficit speciem determinatus a cognitione phantasiae». SuÁrez, F., Commentaria De anima. Tomo 3, Fundación Xavier Zubiri, Madrid, 1991, Disp. IX, q. 4, n. 2, p. 154; "Certum enim est quod intellectus agens non est productivus specierum nisi $\mathrm{ab}$ aliquo determinetur; dum autem anima est in corpore, determinatur intellectus agens a phantasmate». Disp. IV, q. 4, n. 2, p. 474.

45 «[... quia anima non convertitur ad res nisi cognoscendo vel amando illas; haec ergo conversio supponit species in intellectu». SuÁRez, F., Commentaria De anima, Disp. XIV, q. 4, n. 2, p. 474.

46 «[...] in corpore enim cognoscit per conversionem ad phantasma sensibile». SuÁREZ, F., Commentaria De anima, Disp. XIV, q. 4, n. 3, p. 474. 
Desde la filosofía suareciana la propuesta de solución proviene de la doctrina de la simpatía o armonía de facultades, según la cual existe entre las potencias del alma una consonancia por la común radicación en una única alma espiritual, que es a la vez forma de un cuerpo físico con vida sensitiva.

\section{La Simpatía de las facultades En El COMENTARio al DE ANIMA}

La armonía natural de las facultades del alma o teoría de la «simpatía natural de las potencias», no es una doctrina desconocida para los escolásticos medievales. Como señala Spruit: «La solución propuesta por Suárez era, en efecto, una combinación de opiniones, tomadas por una parte de Jean de la Rochelle y Olivi (la idea de una colligantia o simpatía entre el alma y el cuerpo), y por otra parte de Egidio Romano, Capreolo y Silvestre de Ferrara (la teoría de la común radicatio de las facultades de la percepción y de la cognición en el alma humana)» ${ }^{47}$. Ercilla indica por su parte que «ese concepto de simpatía en el sentido que Suárez lo usa como impulso inicial de una actividad tiene probablemente su parentesco en Escoto (Opux Ox., I, d. 3, q. 8, n. 3, y Quod. q. 15, n. 9) y ha ejercido gran influjo en autores escolásticos y escolasticófilos» ${ }^{48}$. Esta doctrina tampoco era desconocida dentro de la escuela tomista. Tomás de Aquino se refiere a ella, aunque se cuida de mantener la diferenciación entre la sensibilidad y la inteligencia humana ${ }^{49}$. Entre los discípulos del Aquinate, Silvestre de Ferrara hace un uso privilegiado de esta común radicación en el alma de la imaginación y del intelecto agente; pero su propuesta presenta el inconveniente de hacer superflua la acción del intelecto agente ${ }^{50}$. Otro tomista como Domingo Báñez — contemporáneo de Suárez y silenciado oponente de sus doctrinas- no tiene inconveniente en acudir a la «común radicación en el

47 SPruIt, L., Species Intelligibilis (II), p. 302.

48 ERcilla, J. DE, De la imagen a la idea, p. 310. Y añade a continuación: «Cuan fácil es el ir descendiendo por ese camino de la simplificación en nombre de la simpatía de potencias, con lo que llegamos sin gran esfuerzo a la comunicación directa e inmediata del fantasma con el entendimiento posible y entonces ya no es fácil distinguir si esos autores siguen a Suárez o entroncan directamente con Durando» [que acaba confundiendo el acto del entendimiento con el de la voluntad]. Ibíd., pp. 310-311, y nt. 54, p. 330.

49 «Es verdad que estas dos potencias que están radicadas en una sustancia del alma, padecen una por la otra mutuamente; pero esta pasión mutua puede entenderse de dos modos: [...] el segundo modo, en cuanto una es movida por la otra. Y esto es posible porque las formas de la imaginación y del sentido son del mismo género, pues tanto una como otra son individuales: y por eso las formas que están en el sentido, pueden imprimir las formas que están en la imaginación que son casi similares a ellas». Tomás de Aquino, $Q$. disp. De anima, a. 4, 1, ad 1. La cursiva es mía.

50 Sobre esta cuestión me remito a García Cuadrado, J. A., La luz del intelecto agente. Estudio desde la metafísica de Báñez, Eunsa, Pamplona, 1998, pp. 222-225. 
alma humana» para explicar la elevación perfectiva de la estimativa en contacto con una potencia espiritual como es el intelecto agente ${ }^{51}$.

Por su parte, Salvador Castellote identifica una fuente próxima al propio Suárez: el médico y filósofo Francisco Vallés de Covarrubias (1524-1592) que adopta el término simpatía aplicándolo a la causalidad entre el alma y el cuerpo. Castellote habla de una causalidad simpática, que no es ni causalidad eficiente ni mero paralelismo psicofísico. Si se aceptara una relación de causalidad eficiente entre el alma y el cuerpo podría caerse en un materialismo (la materia determina al espíritu) o un espiritualismo (el espíritu determina lo material). En todo caso, no es fácil escapar a un implícito dualismo. Vallés trata de superarlo sosteniendo que hay una cierta relación de causalidad entre el alma y el cuerpo pero ésta no es de tipo eficiente, sino de tipo simpático (consensus), exigitivo o excitante ${ }^{52}$. ¿Qué es esa causalidad simpática? Vallés se remite a fenómenos médicos como el dolor: un malestar en el vientre puede producir dolor en la cabeza, pues esa dolencia se localiza en una misma alma, donde cada uno de los elementos corporales influyen en el todo. Una disarmonía en una facultad provoca una disarmonía en las otras, mientras que la armonía de cada potencia hace posible la armonía del todo orgánico. En el fondo parece tratarse de una concepción holística del compuesto humano cuya alma garantizaría la unidad de la persona. Sin embargo, estas indicaciones de Vallés no dejan de ser un tanto imprecisas.

Hacemos notar que Suárez no emplea tampoco el término de «causalidad simpática», aunque asume ampliamente la doctrina de la simpatía de facultades, constituyendo una de las claves fundamentales de su propuesta antropológica. En efecto, de manera explícita se refiere a Vallés cuando argumenta a favor de la unicidad del alma en cada hombre: «La segunda prueba esta tomada de la experiencia considerando la armonía que existe entre las acciones y las facultades del hombre, incluso entre las que pertenecen a distintos grados de almas. No podría darse una armonía tan perfecta, si no existiese un solo principio principal y una sola alma que actuase a través de las otras. Tenemos la experiencia, efectivamente, de que la acción de una facultad entorpece la acción de otra facultad que pertenece incluso al mismo grado de alma. Por ejemplo, cuando alguien durante cierto tiempo se concentra con atención intensa en una actividad intelectual, queda entorpecida la función sensitiva y digestiva. Señal de que es una misma el alma que actúa a través de estas capacidades; por ser limitada su capacidad, cuando se centra en una función, las otras quedan marginadas. Por esta razón en una misma alma sensitiva la acción de un sentido

51 Báñez, D., Scholastica Commentaria, San Esteban, Salamanca, 1588, 731E-732A; 874E. Cf. García Cuadrado, J. A., «Entendimiento agente y razón práctica», en Tópicos 16 (1999), pp. 39-58.

52 Cf. Vallés, F., Controversarium medicarum et philosophicarum, Compluti, 1565, 1, 2. Sigo el trabajo de Castellote, S., «Antropología filosófica en la obra de Francisco de Valles» en Archivo Iberamericano de Historia de la Medicina y Antropología Médica 15 (1963), especialmente pp. 109-112. 
realizada con atención entorpece la acción de otro. De una forma similar se encuentra también esta armonía en las facultades vitales y animales. Cuando una sufre una fuerte alteración, las otras también se alteran. Por ejemplo, si la imaginación percibe con viveza un desprecio, la facultad vital del corazón pone en movimiento los humores y el apetito se vuelve iracundo. Y si percibe un peligro como inminente, se excita el pulso y la facultad natural se altera. Ello esta indicando que todos estos fenómenos radican en una misma alma» ${ }^{53}$.

El Eximio aplica la teoría de la armonía natural de las facultades a los diversos niveles vitales. Por ejemplo, se advierte simpatía entre los sentidos externos e internos: «Los sentidos internos y externos están radicados en la misma alma; luego es una misma alma que ve por la vista y que imagina por la imaginación; en esta armonía natural entre las facultades está por tanto la explicación de que el alma, al punto de percibir algo por la vista, forme inmediatamente en su imaginación una semejanza de aquel objeto, no mediante una facultad distinta de la imaginación, sino por virtud de la misma imaginación; de suerte que dada la sensación externa, surge la especie en el sentido interno, como resultado natural, no por la actividad de la sensación, sino por la actividad justamente del alma, que se vale de la imaginación, si bien ante la presencia del objeto sentido ${ }^{54}$. De esta manera, Suárez hace recaer la eficiencia en el alma para privar a la sensación de toda eficiencia. La actividad es privativa del alma y no de los sentidos que son pasivos con respecto a la sensación ${ }^{55}$. Ciertamente la imaginación precisa de la sensación para producir esta o aquella imagen sensible:

53 «Secunda ratio, a posteriori, sumitur ex consonantia quae est inter operationes et potentias hominis, etiam inter illas quae ad diversos gradus animarum pertinent. Haec enim consonantia tanta esse non posset, nisi esset unum principium principale et una anima quae per omnes illas operaretur. Experimur enim quod operatio unius potentiae impedit operationem alterius potentiae pertinentis etiam ad illum gradum animae; ut si quis nimia attentione incumbat actioni intellectus aliquo tempore, impeditur vis sensitiva et digestiva. Quod est signum eamdem esse animam per has virtutes operantem, quae finitam habet virtutem, et ita dum alteri incumbit, ab aliis distrahitur. Qua ratione in eadem anima sensitiva attenta operatio unius sensus impedit operationem alterius. Et similiter in facultatibus vitalibus et animalibus invenitur haec consonantia, quod una vehementer alterata, alterantur aliae: ut si imaginatio apprehendat vehementer contemptum, facultas vitalis cordis commovet humorem, et appetitio irascitur; et si apprehendat periculum ut imminens, incitatur pulsus, et naturalis facultas alteratur. Quae docent ista omnia esse in eadem anima radicata». SuÁREz, F., Commentaria De Anima, Disp. II, q. 5, n. 5, p. 328.

54 «Sensus interior et exterior in eadem anima radicantur, unde eadem est anima quae videt per visum, et per imaginationem imaginatur est ergo haec naturalis consensio inter has potentias, quod eo ipso quod anima aliquid visu percipit, statim sonat similitudinem illius rei in imaginatione sua, non mediante potentia ab imaginatione distincta, sed per virtutem eiusdem imaginationis, ita ut posita sensatione extrinseca, naturaliter resultet species in interiori sensu, non ex activitate sensationis, sed ex activitate ipsius animae per imaginationem, ad praesentiam tamen rei sensatae». SuÁrez, F., Commentaria De Anima, Disp. VI, q. 2, n. 13, p. 486.

55 El carácter activo del alma se halla presente también a nivel sensible, como se manifiesta en la doctrina suareciana del sentido agente: Cf. LeIJEnhoerst, C., «Cajetan and Suárez on Agent Sense», en Forming the mind: Essays on the internal senses and mind/body problem 
«Por ello precisamente no siempre la imaginación produce dichas especies, pues el alma necesita de algún conocimiento previo del objeto para poder formar dentro de sí alguna semejanza de aquella realidad interior ${ }^{56}$.

Suárez observa que la simpatía entre los sentidos externos e internos se hace extensiva a otras operaciones vitales: «[...] otros numerosos casos de armonía, semejantes a éste, se encuentran en las facultades vitales radicadas en la misma alma, puesto que cuando una opera, opera inmediatamente otra y no acontece de otro modo ${ }^{57}$. El jesuita granadino suscribe con agrado la doctrina de la simpatía de las potencias precisamente porque le servirá para salvar el puente entre lo sensible y lo espiritual, como él mismo reconoce: «este mecanismo va de acuerdo con el estudio posterior sobre el entendimiento, y por ello me satisface extraordinariamente ${ }^{58}$.

En efecto, la armonía natural se halla presente también entre la imaginación y la inteligencia: «Se ha de advertir que la fantasía y el intelecto del hombre están radicados en un alma; y de ahí que en sus operaciones tengan orden y consonancia; de donde después se manifestará de modo claro que por lo mismo que el intelecto opera, también la imaginación opera» ${ }^{59}$. En última instancia, Suárez se remite a la experiencia del sujeto donde la operación de la imaginación parece indiscernible del mismo pensamiento: «Y así resulta que tan pronto como el alma conoce algo por medio de la fantasía, lo pinta, por así decir, en el entendimiento posible por medio de su capacidad espiritual ${ }^{60}$. Todas las facultades cognoscitivas sensibles (tanto sentidos externos como internos) «acompañan» a la inteligencia en su conocer. En última instancia, Suárez apelará a la unidad de la experiencia interna: las potencias son diversas pero la conexión entre ellas por estar radicadas en el alma hace que el sujeto se perciba a sí mismo viendo, imaginando o pensando ${ }^{61}$.

from Avicena to the medical enlightenment, Lagerlund, H. (ed.), Dordrecht, Springer, 2007, pp. 250-262.

56 «Et ideo imaginatio non semper efficit illas species, quia indiget anima praevia aliqua cognitione obiecti, ut possit intra se formare aliquam similitudinem illius». Ibidem.

57 «Denique, quia multae aliae consensiones similis $<$ nominis > reperiuntur in potentiis vitalibus radicatis in eadem anima, nam una operante, statim [alia] operatur, et non alias; ergo similiter, et caetera». Ibidem.

58 «Item, hic modus consonat cum dicendis infra de intellectu, et ideo placet plurimum». Ibidem.

59 «Est enim advertendum phantasiam et intellectum hominis radicari in una anima; et hinc est quod in suis operibus habent ordinem et consonantiam; unde patebit, infra, quod eo ipso quod intellectus operatur, etiam imaginatio operatur». SuÁrez, F., Commentaria De anima, Disp. IX, q. 2, n. 12, p. 96.

${ }^{60}$ «Et ita fit quod statim ac anima per phantasiam cognoscit aliquid, per virtutem suam spiritualem quasi depingit rem illam in intellectu possibili». Ibidem.

61 Para Descartes esa unificación de la experiencia se atribuye a la conciencia: «Suarez uses the causal harmony between aspects of the soul to unify experience - Descartes needs only consciousness. As the functions of the faculties of the soul decrease, the role of consciousness is expanded to fill the explanatory gap». Amaral, P., "Harmony in Descartes and the Medical Philosophers», p. 543. 
El intelecto agente y la fantasía son facultades de la misma alma y su común «raíz» hace posible que puedan colaborar sin ninguna eficiencia real entre ellas $^{62}$. Así pues, en Suárez, la disparidad ontológica de las potencias queda salvada por la común radicación en el alma humana espiritual, sin reconocer una mutua dependencia eficiente entre ellas. Se comprende así el interés del Eximio por no reconocer eficiencia alguna a la fantasía, la cual determina al intelecto agente en una especie. «Esta determinación no se realiza por una eficiencia de la imagen misma, sino suministrando meramente al entendimiento agente la materia y el ejemplar, por así decir, y esto en razón de la unión que tiene lugar en una misma alma» ${ }^{63}$.

La simpatía de facultades se aplica también a la relación entre las potencias apetitivas y las cognoscitivas: «Una explicación semejante cabe respecto tanto de los sentidos internos como de las facultades apetitivas: el apetito es la causa total de su propio acto, en su actividad, sin embargo, depende de la facultad cognoscitiva, porque si no precede el conocimiento, el apetito no puede apetecer nada; pero puesto el conocimiento, el apetito se estimula ${ }^{64}$. De modo semejante, la voluntad es la causa total de la volición, pero precisa de la inteligencia para dirigirse hacia éste o aquel bien previamente conocido. La armonía y la consonancia entre la voluntad y las potencias cognoscitivas explicarían la mutua dependencia y la subordinación de las potencias a la voluntad de cara a la determinación del acto voluntario ${ }^{65}$.

La doctrina de la armonía natural de las potencias se encontrará también presente en las últimas obras suarecinas, como se puede apreciar en este texto sobre los ángeles: «a no ser que [...] el espíritu esté unido al cuerpo, no puede recibir conceptos espirituales de los objetos corporales [...]. La razón es que el espíritu sin la intervención del propio cuerpo informado por el espíritu no

62 Un tratamiento más detallado del intelecto agente según el Eximio puede encontrarse en Rafael Sevilla, «La doctrina del entendimiento agente en la gnoseología de Francisco Suárez», Cuadernos doctorales de Filosofía. Excerpta e dissertationibus in Philosophia, 15 (2005), pp. 9-77.

63 «Haec determinatio non fit per efficientiam aliquam ipsius phantasmatis, sed per hoc solum quod materiam praebet et quasi exemplar intellectui agenti, idque propter unionem quam habet in eadem anima». SuÁrez, F., Commentaria De anima, Disp. IX, q. 2, n. 12, p. 94. La cursiva es mía.

${ }^{64}$ «Et a simili potest explicari tum in sensibus interioribus, tum in potentiis appetitivis. Est enim appetitus totalis causa sui actus, ut infra dicetur, pendens tamen in operatione sua a potentia cognoscente, nam nisi praecedat cognitio, appetitus nihil potest appetere; posita autem cognitione excitatur appetitus». SuÁrez, F., Commentaria De Anima, Disp. IX, q. 2, n. 12, p. 96.

65 «Ultimo nota quod ista motio voluntatis, a qua effective dicuntur moveri aliae potentiae, non est sic intelligenda ac si per illam aliquid voluntas ponat in aliis potentiis, vel aliquo modo immediate concurrat ad eliciendos actus aliarum potentiarum, sed tantum est quaedam moralis motio, quae in Physica est efficientia per accidens, in Philosophia autem morali censetur per se, et provenit tantum ex consensione istarum potentiarum, quae in eadem anima radicantur et habent inter se dictam subordinationem naturalem». SuÁrez, F., Commentaria De Anima, Disp. XII, q. 2, n. 8, p. 380. 
puede de modo inmediato recibir la especie de lo material, porque de modo natural no puede el espíritu inmediata y directamente padecer, ser causado o excitado por un objeto material, porque esto es completamente desproporcionado al espíritu. Por lo tanto, para que el espíritu pueda ser excitado por lo corpóreo, es necesario que esté unido naturalmente al cuerpo, y que mediante él incoe el conocimiento, ya que sin los sentidos no puede conocer, y por eso no puede recibir especies de las cosas materiales sin la intervención de los sentidos. Y no importa que el conocimiento de los sentidos y la fantasía sea material porque en el hombre están radicados en la misma alma espiritual, y esto es suficiente para que con su ministerio el intelecto reciba la especie a él proporcionado» ${ }^{66}$.

\section{La armonía natural en las Disputaciones Metafísicas}

Por lo expuesto anteriormente podemos concluir que Suárez introduce una sustancial modificación en la gnoseología aristotélica, a propósito de su tratamiento de la causalidad instrumental de las imágenes: lo material no posee ninguna eficiencia, ni siquiera instrumental, sobre lo espiritual. Sin embargo, en las Disputaciones Metafísicas parece manifestarse un importante cambio en su concepción sobre el concurso de la imagen, siguiendo ahora la habitual interpretación tomista de las imágenes como causas instrumentales. En efecto, en la Disputación XXI trata de «la primera causa eficiente y su segunda acción, que es la conservación»; en la sección III se pregunta si todas las cosas dependen solo de Dios en su conservación. Suárez distingue — siguiendo a Tomás de Aquino- entre la producción y la conservación de los efectos: «En general, ningún efecto más noble que el instrumento parece depender por sí mismo en su conservación de la acción del instrumento, aun cuando a veces dependa en su producción, puesto que tal agente no es apto para producir tal efecto sino mediante el instrumento, de igual modo que la especie inteligible, aunque es producida mediante la imagen en calidad de instrumento, no depende de él en su conservación, y así en otros casos ${ }^{67}$. De lo que se desprende que el Eximio

${ }^{66}$ «nisi $[\ldots]$ spiritus uniatur corpori, non potest a corporalibus obiectis species spirituales accipere [...] Ratio autem, de qua sine interventu proprii corporis informati a spiritu non possit spiritus immediate a materiali speciem accipere, est, quia naturaliter non potest spiritus immediate et directe pati aut effici, aut excitari ab obiecto materiali, quia est spiritui omnino improportionatum. Ut ergo spiritus a corporeo obiecto excitetur, necessarium est ut sit naturaliter unitus corpori, et quod per illum cognitionem inchoet, quod sine sensibus facere non potest, et ideo fieri non potest, ut sine ministerio sensuum spiritualis potentia species a rebus materialibus accipt. Nec refert quod cognitio sensuum et phantasiae materialis sit, quia in homine sunt radicatae in eadem anima spirituali, et id satis est ut per eius ministerium intellectus speciem sibi proportionatam accipiat». SuÁrez, F., De Angelis, Lib. I, cap. 6, n. 24, p. 133.

67 «[...] in universum nullus effectus nobilior instrumento videtur per se pendere in conservari ab actione instrumenti, esto interdum, quia tale agens non est aptum ad efficiendum talem effectum nisi medio instrumento; ut, licet species intelligibilis fiat medio phantasmate ut 
reconoce el carácter instrumental de la imagen para la producción de la especie inteligible, aunque no dependa de la imagen para permanecer en el intelecto paciente. De esta manera, se salva la inmaterialidad y espiritualidad de la inteligencia que no conserva nada material, aunque para llegar a representar tal especie inteligible determinada precise del concurso de la imagen sensible.

Se mantiene aquí el principio de que la imagen sensible — material- produce un efecto más perfecto que su propia capacidad — la espiritualidad de la especie inteligible-, pero tal efecto es producido por un agente espiritual —el entendimiento agente- - La necesidad de la imagen sensible no se funda en su naturaleza material sino en la eficiencia del agente. En efecto, como añade el Eximio: «la relación a un instrumento menos perfecto no puede fundarse en la intrínseca naturaleza e indigencia del efecto mismo, sino, a lo sumo, en la naturaleza o voluntad del agente, porque o no es suficiente o no quiere obrar sin tal instrumento. [...] Pues siempre que la causa, mediante un instrumento imperfecto, realiza un efecto perfecto, es causa de la producción mas no del ser, porque no es verosímil que tal efecto, en virtud de su ser considerado absolutamente, exija tal causa para existir, sino, a lo sumo, para ser hecho con tal género de producción. Y por ello tal efecto nunca depende de tal causa en su conservación ${ }^{68}$.

Esta afirmación parece contradecir lo expresado en el comentario juvenil al De anima. Cuando el Doctor Eximio murió, en 1617, sólo pudo revisar los primeros doce capítulos del libro primero del De anima, por lo que se puede suponer una rectificación de su posición con respecto a si la imagen participa con una causalidad eficiente instrumental en la formación de las especies inteligibles. El estado de la cuestión, dentro de la escolástica suareciana, ha sido expuesto con cierto detalle, sin llegar a un acuerdo entre sus intérpretes ${ }^{69}$.

En mi opinión, tal cambio de postura no tuvo lugar, precisamente porque la negación de la causalidad eficiente-instrumental de la imagen es solidaria con la tesis de la dependencia concomitante inscrita en la doctrina de la simpatía de las potencias. Esta última doctrina fue mantenida por Suárez hasta sus últimos escritos, no sólo en su tratado De angelis, sino también en la revisión -que no pudo culminar- del comentario al De anima. Si en las Disputationes Metafísicas menciona que las imágenes son instrumentos del intelecto de cara a la producción de las especies inteligibles, puede deberse al uso impropio de

instrumento, non pendet ab illo in conservari, et sic de aliis». SuÁREz, F., Disputaciones Metafísicas. III, Disp. XXI, sec. III, n. 7, pp. 577-578. La cursiva en el texto es nuestra.

68 «Et ratio esse videtur quia habitudo ad instrumentum ignobilius non potest fundari in intrinseca natura et indigentia ipsius effectus, sed ad summum in natura vel voluntate agentis, quia vel non est sufficiens vel non vult agere sine tali instrumento. [...] Nam quandocumque causa medio instrumento imperfecto agit perfectum effectum, est causa ipsius fieri, non vero ipsius esse, quia non est verisimile talem effectum ex vi sui esse absolute considerati postulare talem causam ut sit, sed ad summum ut fiat tali genere productionis. Et ideo talis effectus nunquam pendet a tali causa in conservari». Ibidem.

69 Cf. Ercilla, J., De la imagen a la idea..., pp. 311-312. En el Apéndice I de este libro (pp. 287-333) se encuentra un excelente estado de la cuestión. 
las palabras, como él mismo también admitía en su juvenil comentario al $D e$ anima. También en la versión revisada, Suárez admite, aunque con ciertas reticencias, el empleo de «instrumento» aplicado al concurso de las imágenes ${ }^{70}$.

En todo caso, dentro de las Disputaciones Metafísicas encontramos buenos argumentos para no avalar un cambio de postura en Suárez, precisamente por la defensa de la simpatía de las facultades. Así por ejemplo, en las Disputación XVIII, se pregunta si los accidentes solos, sin el concurso de las formas sustanciales, producen otros accidentes. En su argumentación afirma que en las funciones vitales no influye sólo el accidente, sino también la sustancia de manera próxima, según puede apreciar por la experiencia: «en efecto, estas acciones vitales se realizan de un modo tan íntimo que dan la impresión de proceder actualmente del primer principio vital, que es el alma; de aquí resulta que, aun cuando el ojo tenga en su presencia una imagen y reciba de ella la especie, no ve si el alma no atiende ${ }^{71}$. Se introduce aquí la doctrina psicológica de la atención que es solidaria a su vez con la simpatía de facultades, ya que «es preciso que exista algún principio común que se valga en acto de esas dos facultades y, por natural inclinación o simpatía, ordene la acción de una al acto de la otra ${ }^{72}$. Suárez acude de nuevo a la experiencia interna: la unicidad del alma humana hace que el ejercicio de una facultad impide o entorpece el ejercicio de las demás: "porque la excesiva atención a la operación de una facultad impide la operación de otra; por ejemplo, si un hombre mira algo con demasiada atención, no oirá a quien le hable; [...] también la atención intelectual impide la operación del sentido y, cuanto más elevada y perfecta es, tanto más aminora también el movimiento o la representación de la fantasía, e incluso (lo que es más aún) llega a estorbar o suspender las operaciones de la facultad nutritiva. Ahora bien, si cada facultad ejerciese por sí sola su operación, no habría motivo para que la operación de una impidiese la de otra, ya que, multiplicadas las facultades, si una no depende de otra ni ambas dependen de un tercero cuya virtud disminuya en cada una cuando se aplica a las dos, no hay razón para que sus operaciones no puedan multiplicarse a un mismo tiempo y ejercerse de manera igualmente perfecta» ${ }^{73}$.

70 «[...] et phantasma solum prerequiritur, vel ut occasio excitans, et vel ut exemplat, vel ad summum, ut instrumentum elevatum per spirituale lumen eiusdem animae». SuÁREz, F., Tractatus de anima. Lib. I, Cap. XI, n. 21, p. 550.

71 «[... ] nam hae acciones vitales tam intimo modo fiunt ut ab ipso primo principio vitae, quod est anima, actualiter procedere videantur; unde fit ut, licet oculus praesentem habeat imaginem et ab illa recipiat speciem, si anima non attendat, non videat». Suárez, F., Disputaciones Metafísicas. III, Disp. XVIII, sec. V, n. 2, p. 165.

72 «[...] ergo necesse est ut sit aliquod commune principium actu utens illis duabus facultatibus, et ex naturali inclinatione vel sympathia ordinans actionem unius ad actum alterius». Ibíd., p. 166. La cursiva es mía.

73 «[...] quia nimirum ex nimia attentione ad opus unius facultatis impeditur in opere alterius, ut si nimis atttente aliquid homo inspiciat, non audiet loquentem; [...] etiam attentio intellectus impedit operationem sensus, eo plus minuit etiam phantasiae motum aut raepresentationem et (quod magis est) etiam opera nutritivae partis impedit vel suspendit. Si autem 
Suárez da un paso más: no es la mera radicación de las facultades en una misma alma, sino la mutua conexión de sus operaciones entre sí lo que explica la acción humana: «Por otra parte, de la conexión de las operaciones se toma un excelente argumento a contrario; efectivamente, mientras el entendimiento entiende, la voluntad es excitada a amar, etc.; pero ello obedece a que la misma alma obra en acto mediante ambas potencias, pues la sola radicación habitual, por así decirlo, o remota dimanación a partir de una misma alma no bastaría para esta causalidad actual o moción y excitación, si cada una de las operaciones procediese actualmente de su potencia sola sin tener conexión en algún principio común. Y de ahí nace también la dependencia entre el apetito vital y el conocimiento, de suerte que no puede amarse nada que no se haya conocido previamente» ${ }^{74}$.

Unas páginas más adelante, en esa misma disputación, Suárez trata de cómo actúa la fantasía sobre el apetito. En primer lugar, consigna la idea de que debe haber una cierta proximidad física, ya sea directamente o ya sea a través de un medio por el que se comunique la noticia de las especies. Suárez, sin embargo, pretende escapar a esta concepción recurriendo de nuevo a la teoría de la simpatía de las potencias: la noticia no concurre activamente al acto del apetito; se trata simplemente «de una condición representativa del objeto, puesta la cual el apetito produce su acto por simpatía natural entre estas potencias. Y constituye una excelente ayuda para esto la radicación de dichas facultades en una misma alma; porque ella, o el supuesto mediante ella, es quien principalmente obra y se vale de estas facultades, por lo cual, mientras por medio de una percibe el objeto que le es conveniente, por medio de la otra lo apetece. No es que por medio de una obre en la otra, sino que, merced al objeto aprehendido mediante una, es excitada a obrar mediante la otra, excitación que no tiene lugar por una inmutación real y efectiva, sino metafórica o final, no exigiendo, por tanto, proximidad local, sino anímica, por así decirlo» ${ }^{75}$. En definitiva, la

unaquaeque facultas sola per seipsam haberet suam operationem, nulla esset ratio cur inius operatio impediret operationem alterius; nam multiplicatis virtutibus, si una ab altera non pendet, neque ambae ab uno tertio, cuius virtus, dum utrique applicatur, minuatur in singulis, nihil est cur earum operationes non possint simul multiplicari et exerceri aeque perfecte». Ibid., p. 166.

74 «Praeterea sumitur a contrario optimum argumentum ex connexione operationum; nam dum intellectus intelligit, voluntas excitatur ad amandum, etc.; hoc autem ideo est quia eadem anima per utramque potentiam actu operatur, nam sola veluti habitualis radicatio seu remota dimanatio ab eadem anima non esset satis ad hanc actualem causalitatem seu motionem et excitationem, si unaquaeque operatio a sua sola potentia actualiter prodiret sine connexione in aliquo communi principio. Et inde etiam oritur dependentia inter appetitum vitae et cognitionem, ut nihil possit esse amatum nisi sit praecognitum». Ibidem. La cursiva es del texto.

75 «Et ideo nos facilius has angustias evademus negando notitiam concurrere active ad actum appetitus, sed tantum ut conditionem repraesentantem obiectum, qua posita, appetitus efficit suum actum per naturalem sympathiam harum potentiarum. Et ad hoc optime confert radicatio illarum facultatum in eadem anima; illa enim, seu suppositum per illam, est quod principaliter operatur et utitur his facultibus, et ideo, dum per unam percipit obiectum 
relación entre las facultades sensitivas e intelectivas no requiere ningún contacto físico para la operación: «la aplicación de la potencia motriz por medio del apetito no se realiza por acción propia y física de una potencia sobre otra, sino por subordinación de las potencias en la misma alma; de este modo también el entendimiento y el sentido se aplican a la operación por medio de la voluntad y el apetito» ${ }^{76}$.

Como se puede observar, la doctrina de la simpatía de las facultades mantiene toda su vigencia en el Suárez que elaboró las Disputaciones Metafísicas, lo cual nos hace pensar que en su reelaboración de las cuestiones psicológicas, que no pudo concluir, seguiría manteniendo esta idea.

\section{De la armonía natural a la concomitancia de FACUltades}

Ha llegado el momento de volver a la cuestión planteada al inicio de nuestro trabajo para preguntamos hasta qué punto la simpatía de potencias es capaz de solventar el problema de la comunicación entre el alma y el cuerpo. Es difícil evaluar el alcance de la propuesta suareciana. Es evidente su intención de mantener la unidad sustancial del hombre al tiempo que deja abierta la posibilidad de argumentar a favor de la espiritualidad del alma humana. Suárez hace hábiles equilibrios para salvar los dos extremos, y por eso es posible encontrar textos suyos en donde se subraya la unidad sustancial, junto a otros donde parece admitirse un cierto paralelismo psicofísico.

Así por ejemplo, al tratar de la producción de la especie sensible admite «la tesis de que mediante la acción cognoscitiva se produce cierto termino intrínseco de la misma, que es una cualidad que representa el objeto en acto segundo; es por tanto probablemente verosímil que mediante esta cualidad que el sentido externo forma en sí propio se produzca en el sentido interno cierta especie que representa el mismo objeto. Y ello en virtud de la coordinación y unión que posee en esas dos facultades en una misma alma» ${ }^{77}$. De este texto no nos sorprende hallar de nuevo la doctrina de la armonía de las potencias, sino más

sibi convenniens, per aliam illud apetit; non quidem quia per unam efficiat in aliam, sed quia ex obiecto per unam apprehenso excitatio non est per immutationem realem et effectivam, sed per metaphoricam seu finalem, et ideo non requirit localem propinquitatem, sed animalem, ut sic dicam». Suárez, F., Disputaciones Metafísicas. III, Disp. XVIII, sec. VIII, n. 40, p. 255-256.

76 «[...] applicatio potentiae motivae per appetitum non est per actionem propriam et physicam unius potentiae in aliam, sed per subordinationem potentiarum in eadem anima; quo modo etiam intellectus et sensu applicantur ad operandum per voluntatem et appetitum». Ibidem.

77 «Ad intelligendam vero partem secundam oportet resumere ex disputatione praecedenti quod per actionem cognoscendi producitur quidam intrinsecus terminus illius, qui est qualitas repraesentativa rei in actu secundo; per hanc ergo qualitatem, quam sensus exterior in se ipso format, potest probabiliter credi produci in sensu interiori speciem quamdam repraesentativam eiusdem obiecti, idque propter coordinationem et unionem quam istae duae 
bien el hecho de reconocer dos operaciones coordinadas en una única alma. No hay una relación causa-efecto, sino una mutua interrelación coordinada entre las dos potencias. Al tratar de la relación entre el intelecto y la fantasía, Suárez utiliza el término concomitancia, que vendría a ser lo mismo que la causalidad simpática de Vallés; por eso, utiliza indistintamente concomitancia o simpatía.

Este tipo de afirmaciones han llevado a pensar que Suárez no logra escapar del todo de la tentación dualista en su empeño por salvaguardar la espiritualidad del alma. Como señala Spruit: «Intelecto y fantasía no cooperan causalmente, pero tienen actos simultáneos o paralelos ${ }^{78}$. La consecuencia que este autor saca es que Suárez incurre en una especie de ocasionalismo gnoseológico, pues la sensación externa se convierte en la ocasión para que el alma actúe ${ }^{79}$.

Un observatorio privilegiado para perfilar mejor la propuesta gnoseológica del Eximio se encuentra en el comentario de las palabras de Aristóteles de que "el pensar no se da sin fantasía ${ }^{80}$. En el comentario al De anima, Suárez apunta cual es en su opinión la interpretación adecuada a las palabras del Estagirita: «la actividad de una facultad de tres maneras puede depender de una determinada facultad material. Una manera, en cuanto productora; así ocurre con el acto de la imaginación respecto de la fantasía misma. Otra manera, en cuanto propone un objeto que pertenece a un mismo orden y especie; así ocurre con la actividad de la pulsión sensitiva respecto de la fantasía, y con la actividad de la fantasía respecto de los sentidos externos. [...] Una tercera manera de depender la actividad de una facultad respecto de otra es por concomitancia; así ocurre con nuestro entender respecto de la fantasía, ya que la actividad de la fantasía siempre acompaña a la actividad del entendimiento» ${ }^{81}$.

potentiae habent in eadem anima». Sú́rez, F., Commentaria De Anima, Disp. VI, q. 2, n. 10, p. 482. La cursiva es mía.

78 "Intellect and phantasy do not so much causally cooperate, but they have simultaneous or parallel acts». SpRUIT, L., Species Intelligibilis (II), p. 302. La cursiva es mía.

79 Los ecos del neoplatonismo se encuentran muy presentes y, consecuentemente, un dualismo implícito: "The occasionalist explanation of the sense-dependence of intellective cognition is a clear token of Suarez's affinity with Neoplatonic interpretations of Aristotle's psychology», Ibid., p. 304.

80 «En la mayoría de los casos se puede observar como el alma no hace ni padece nada sin el cuerpo, por ejemplo, encolerizarse, envalentonarse, apetecer, sentir en general. No obstante, el inteligir parece algo particularmente exclusivo de ella; pero ni esto siquiera podrá tener lugar sin el cuerpo si es que se trata de un cierto tipo de imaginación o de algo que no se da sin imaginación». Aristóteles, De anima I, 1, 403a 6-9. Un estudio de la interpretación suareciana de este pasaje se encuentra en Salvador Castellote, «La recepción suareciana del concepto aristotélico de "separabilidad" del alma humana», en Verdad. Percepción. Inmortalidad. Wahrheit, Wahrehmung, Ubsterblichteik, Miscelánea en homenaje al Profesor Wolfgang Strobl, (S. Castellote, ed.), Facultad de Teología San Vicente Ferrer, Valencia, 1995, pp. 137-149.

81 «Ad cuius intelligentiam nota quod tripliciter operatio unius potentiae potest dependere ab aliqua materiali potentia: Uno modo tamquam ab elicienti, ut pendet actus imaginandi a phantasia ipsa. Secundo modo tamquam a proponente obiectum eiusdem ordinis et rationis, ut pendet operatio appetitus sensitivi a phantasia, et operatio phantasiae a sensibus externis, [...]. Tertio modo pendet operatio unius potentiae ab alia, tamquam a concomitante, ut pendet intelligere nostrum a phantasia, quia operatio phantasiae semper concomitatur 
En la redacción revisada de su comentario al De anima, publicada después de su muerte por Baltasar Álvarez, Suárez explica con más detalle su postura. «Se ha de decir, por tanto, que parece que además de la dependencia de una operación de la fantasía, como por el órgano, o instrumento, o facultad que elicita la operación, de otros dos modos puede una operación no darse sin la fantasía. De un modo esencialmente antecedente (antecedenter per se) y causalmente; de otro modo consecuente o concomitante, y casi por accidente» ${ }^{82}$. Como ejemplo de la primera aduce la dependencia que tiene el apetito respecto de la fantasía porque aquel no puede darse sin esta, al igual que sucede con la imaginación que depende de la sensación externa. Igualmente, de modo antecedente, el intelecto paciente depende causalmente del intelecto agente: éste es causa eficiente y aquel es la causa material. En ambos casos se da una prioridad causal de la causa con respecto al efecto. No obstante, el intelecto agente depende de la fantasía sólo como prerrequisito, ocasión o ejemplar, pero no como causa eficiente. Por esta razón, añade como ejemplo de dependencia concomitante el entender, porque en su operación precisa de las imágenes. El propio entender, en sí mismo, no es una imaginación ni tampoco depende de la imaginación actualmente, de manera esencial, sino solamente por una cierta simpatía natural o concomitancia que se sigue de la natural unión del alma con el cuerpo ${ }^{83}$.

Si existiese una dependencia esencial entre el acto de entender y la fantasía, entonces, el entender sería producido por la fantasía y no sería separable de la fantasía, ni tendría una operación propia, sino que se daría mediante una potencia orgánica $^{84}$. Esta explicación comprometería la espiritualidad del alma y su inmortalidad; pero además contradice la doctrina del mismo Aristóteles, para quien el intelecto no posee ningún órgano corporal por ser inmaterial, impasible y algo divino. Para salvar la inmaterialidad del intelecto, Suárez intro-

operationem intellectus, ut infra dicitur». SuÁRez, F., Commentaria De Anima, Disp. II, q. 3, n. 45 , p. 228.

82 «Videtur ergo dicendum praeter dependentiam alicuius operationis a phantasia, ut ab organo vel instrumento, seu facultate eliciente operationem duobus aliis modis posse aliquam operationem non esse sine phantasia. Uno modo antecedenter per se, et causaliter: alio modo consequenter, vel concomitanter, et quasi ex accidenti». SuÁrez, F., Tractatus de anima. Lib. I, Cap. XI, n. 19, p. 549.

83 «Posteriori autem modo dicitur intelligere animae coniunctae non esse sine phantasia, quia necesse est intelligentem phantasmata speculari, non quia ipsum intelligere per se spectatum ab actuali imaginatione per se pendeat, sed solum per quamdam naturalem sympathiam, seu concomitantiam, quae sequitur ex naturali unione animae ad corpus». Ibidem. La cursiva es mía.

${ }^{84}$ «Quando ergo operatio, licet non sit imaginatio, sine illa esse non potest priori modo, id est, ratione alicuius dependentiae per se ab illa: tunc vel est illa propositio disiunctiva, $S i$ operatio est phantasia, vel non est sine phantasia, non est separabilis, quia talis dependentia recte indicat illam potentiam esse eiusdem ordinis cum ipsa phantasia, et esse organicam, sicut est illa, et ita contingit in dicto exemplo de appetitu sensitivo, et fortasse idem est de potentia animae motiva corporis secundum locum». Ibíd., n. 20. La cursiva se encuentra en el texto. 
duce la teoría de la concomitancia o dependencia accidental, en la que sostiene que si la operación del intelecto no puede darse sin fantasía, ello es sólo de un modo posterior, sin dependencia esencial, sino por concomitancia, donde la fantasía es un prerrequisito u ocasión que excita al intelecto. Tal concomitancia no surge de la intrínseca naturaleza de la operación, ni es propio de sus principios, sino que procede de otros principios o circunstancias ${ }^{85}$. En el fondo, para Suárez, la imagen es solo ocasión ${ }^{86}$ o condición, pero nunca causa eficiente en la producción de las especies inteligibles.

\section{DE la CONCOMitancia A LA ACAUSALIDAD DEL CONOCER}

El examen de los textos suarecianos nos revela la dificultad que encuentra en admitir la causalidad en el conocer. Cuando Suárez habla de alguna causalidad (ya sea material, instrumental o ejemplar) no deja de manifestar la impropiedad de tales categorías. Tampoco habla propiamente de una causalidad simpática, o exigitiva o determinativa, como alguno de sus comentadores actuales ha propuesto: esa interpretación es posible dentro del contexto suareciano, pero Suárez no emplea esas categorías de modo explícito. Todo ello ha llevado a pensar que el Eximio niega que exista propiamente una causalidad en el conocer. Esta es la opinión de Ludwig, para quien Suárez sostiene una relación acausal entre las facultades ${ }^{87}$. Y esta parece ser también la interpretación de Spruit ${ }^{88}$.

Otros autores, por el contrario, no apoyan esta interpretación de la acausalidad del conocer. Así, por ejemplo, Amaral afirma que el Eximio no niega que haya una causalidad, sino que dicha causalidad sea eficiente de tipo físico, casi mecanicista; y propone otra causalidad de tipo espiritual ${ }^{89}$. Para avalar sus

85 «At vero si operatio non possit esse sine phantasia tantum posteriori modo, scilicet, quia illam excitat, et concomitantem habet, tunc non sequitur talem operationem esse inseparabilem a materia, sicut est ipsa phantasia, quia potest illa concomitantia esse accidentalis, et non oriri ex intrinseca natura operationis, vel propriis eius principiis, sed aliunde, scilicet ex statu, vel alia conditione simili». Ibidem. También cf. Ibíd., n. 21.

86 En algunos textos llega a afirmar que la imagen es «ocasión que excita» al intelecto para conocer. «Et phantasma solum prerequiritur, vel ut occasio excitans, et vel ut exemplat, vel ad summum, ut instrumentum elevatum per spirituale lumen eiusdem animae». SUÁREZ, F., Tractatus de anima. Lib. I, Cap. XI, n. 21, p. 550. La cursiva es mía.

87 Cf. Ludwig, J., Das akausale Zusammenwriken (simpathia) der Seelenvermögen in der Erkenntnishlehre des Suarez, Karl Ludwig-Verlag München, 1929.

88 "The occasional and non-causal character of Suarez's sense-dependency clearly anticipated Descartes' theory of the origin of perceptual ideas». L. Spruit, Species Intelligibilis (II), p. 385 .

89 "The idea that sympathy (harmony) is an inexplicable acausal relationship is clearly rejected. Even the ordo potentiarum, which Suarez explains through his theory of dimanation, is causal; not, however, in the narrow sense of efficient (physical) causality but in the broader sense of metaphysical causality». Amaral, P., "Harmony in Descartes and the Medical Philosophers», p. 533; "Suarez' view can be summarized as follows: between subordinate 
afirmaciones acude a un texto ya citado anteriormente acerca de la relación de las potencias cognoscitivas y apetitivas en el hombre, las cuales se encuentran armónicamente relacionadas en virtud de la común radicación en una misma alma: «[...] porque ella, o el supuesto mediante ella, es quien principalmente obra y se vale de estas facultades, por lo cual, mientras por medio de una percibe el objeto que le es conveniente, por medio de la otra lo apetece; no es que por medio de una obre en la otra, sino que, merced al objeto aprehendido mediante una, es excitada a obrar mediante la otra, excitación que no tiene lugar por una inmutación real y efectiva, sino metafórica o final, no exigiendo, por tanto, proximidad local, sino anímica, por así decirlo» ${ }^{90}$. En definitiva, la relación entre las facultades sensitivas e intelectivas no requiere ningún contacto físico para la operación: "la aplicación de la potencia motriz por medio del apetito no se realiza por acción propia y física de una potencia sobre otra, sino por subordinación de las potencias en la misma alma; de este modo también el entendimiento y el sentido se aplican a la operación por medio de la voluntad y el apetito» ${ }^{91}$. El texto anterior le parece a Amaral de capital importancia, pues se manifiesta que Suárez está hablando de un tipo de causalidad que no requiere contacto físico, sino "anímico» (que Amaral traduce por «espiritual») ${ }^{92}$. Sin embargo, en los textos suarecianos aducidos por Amaral no se habla explícitamente de este tipo de causalidad espiritual, aunque sí de una cierta dependencia de unas facultades de otras por la común radicación en una misma alma ${ }^{93}$.

En este sentido, quisiera traer un último texto de la Disputaciones Metafísicas que ha generado dificultades de interpretación. Se trata de un texto aducido por Amaral para hacer ver que Suárez rechaza la «acausalidad» en el conocer intelectual $^{94}$. El Eximio está tratando de cómo tiene lugar la locución mutua

faculties where there is no clear medium interceding, causation is metaphysical; between inner and outer sense there can be physical causality since there is a medium (as in the case of vision)». Ibid., p. 534.

90 «Et ideo nos facilius has angustias evademus negando notitiam concurrere active ad actum appetitus, sed tantum ut conditionem repraesentantem obiectum, qua posita, appetitus efficit suum actum per naturalem sympathiam harum potentiarum. Et ad hoc optime confert radicatio illarum facultatum in eadem anima; illa enim, seu suppositum per illam, est quod principaliter operatur et utitur his facultibus, et ideo, dum per unam percipit obiectum sibi convenniens, per aliam illud apetit; non quidem quia per unam efficiat in aliam, sed quia ex obiecto per unam apprehenso excitatio non est per immutationem realem et effectivam, sed per metaphoricam seu finalem, et ideo non requirit localem propinquitatem, sed animalem, ut sic dicam». Suárez, F., Disputaciones Metafísicas. III, Disp. XVIII, sec. VIII, n. 40, p. 255-256.

91 «[...] applicatio potentiae motivae per appetitum non est per actionem propriam et physicam unius potentiae in aliam, sed per subordinationem potentiarum in eadem anima; quo modo etiam intellectus et sensu applicantur ad operandum per voluntatem et appetitum». Ibidem.

92 Cf. Amaral, P., «Harmony in Descartes and the Medical Philosophers», pp. 532-533.

93 Suárez, F., Commentaria De Anima, Disp. II, q. 3, n. 54, p. 246; Disp. II, q. 5, n. 5, pp. 328-330; Disp. II, q. 7, n. 11, $1^{\text {a }}$ experientia, p. 20; Disp. III, q. 3, n. 17, pp. 142-144.

94 Cf. Amaral, P., «Harmony in Descartes and the Medical Philosophers», p. 553, nt. 164. 
entre los ángeles. También aquí hay una común simpatía natural y no una acción transeúnte de un ángel a otro. Pero esta explicación tiene también su dificultad, «a saber, que unas facultades radicadas en esencias o sustancias diversas tengan entre sí una natural simpatía y conexión y una concomitancia en el obrar, no causal, pero infalible y esencial, sin acción de una sobre otra ${ }^{95}$. En efecto, ¿cómo explicar la simpatía de facultades en sustancias diversas donde no hay una conexión entre ellas? Sin una verdadera acción de una facultad sobre otra no parece posible una relación; pero ¿de qué tipo sería esa relación? El texto de Suárez parece decir que se trata de una relación «no causal», con lo que vendría avalada la tesis de Ludwig sobre la «acausalidad» simpática.

En realidad, la interpretación se complica más al leer la anotación de los editores de las Disputaciones: "Otras ediciones traen "casualem" en vez de "causalem", que es lo que se lee en la de Vivès. Consideramos esta lectura más en consonancia con el contexto» ${ }^{96}$. No obstante, en mi opinión la lectura casualem podría ser también sostenida: «que unas facultades radicadas en esencias o sustancias diversas tengan entre sí una natural simpatía y conexión y una concomitancia en el obrar, no casual, sino infalible y esencial, sin acción de una sobre otra». Es decir, la dificultad estribaría en cómo explicar en sustancias distintas la conexión entre las facultades y la concomitancia en el obrar, no por casualidad (por el contexto podría decirse «de modo accidental») sino de manera esencial y necesaria, sin la acción de una sustancia sobre la otra. En todo caso, parece que Suárez evita hablar de causalidad entre las potencias, ni siquiera de un tipo de causalidad simpática o espiritual.

\section{Conclusión}

Suárez advierte el problema de la comunicación entre la dimensión material y la espiritual, y opta, como es característico de su talante intelectual, por ensayar nuevas fórmulas y categorías filosóficas para dar una explicación coherente para un problema que parecía irresoluble en las categorías escolásticas. Para ello adopta la doctrina de la simpatía, según la cual, el alma humana espiritual y orgánica a la vez actúa como puente de unión entre esos dos mundos. Al mantener la prioridad de la actividad de la inteligencia sobre la posible eficiencia de las imágenes repropone la doctrina psicológica de la atención ${ }^{97}$; pero no

95 «[...] facultates radicatae in diversis essentiis vel substantiis habeant inter se naturalem sympathiam et connexionem ac concomitantiam in agendo, non causalem, sed infallibilem ac per se, sine accione unius in aliam». SuÁrez, F., Disputaciones Metafísicas. III, Disp. XVIII, sec. VIII, n. 45, p. 259.

96 SuÁrez, F., Disputaciones Metafísicas. III, Disp. XVIII, sec. VIII, n. 45, p. 259, nt. 1.

97 La atención, vendrá a ser una disposición activa del intelecto para el conocimiento, y se encuentra ya presente en Pedro Olivi: «Like this medieval master, Suarez ruled out any direct influence of sense on mind, and attached great importance to the mind's «attentio» in the generation of knowledge». SPRUIT, L., Species Intelligibilis (II), p. 306. 
puede evitar hablar de una dependencia concomitante ni de una coordinación de las causas que parece abocar a una especie de ocasionalismo cognoscitivo como ha sido puesto de relieve por diversos críticos contemporáneos: la teoría de la armonía natural de las potencias sería un caso particular de la «armonía preestablecida» de Descartes o Leibniz ${ }^{98}$; así también las afirmaciones sobre concomitancia de las potencias parece estar latente en el dualismo cartesiano ${ }^{99}$.

En todo caso, cabe destacar que el propósito del Doctor Eximio es principalmente mostrar la insuficiencia de las categorías escolásticas de la causalidad para explicar la índole específica del conocer humano. Por eso recurre a mostrar la impropiedad del lenguaje, a hacer precisiones con las que intenta salvar la especificidad del inteligir. Los críticos inmediatamente posteriores le achacarán esta falta de precisión, como se muestra en este elocuente texto de Juan de Santo Tomás: «decir "a la manera" deja la cuestión oscura y sin explicación, porque aquí de lo que se trata es de averiguar qué concurso verdadera y propiamente tiene la imagen, no a qué clase de concurso se parece. Porque ser a la manera de materia o ejemplar, o saca a la imagen de la verdadera y propia causalidad material o ejemplar, o la deja dentro de los límites de tal causalidad. Si la saca, queda por explicar en qué otra causalidad se pone a la imagen; si la deja, entonces no es "a la manera", sino verdadera y propiamente materia o ejemplar» ${ }^{100}$. Parece que el dominico Juan Poinsot está más imbuido del afán de claridad y distinción cartesiana que el propio Suárez, quien, por el contrario, alcanza a vislumbrar el problema de la índole ontológica del conocer aunque sin alcanzar a explicarlo más que de manera metafórica e impropia.

Quizás Suárez no sea el principal responsable, en última instancia, de los derroteros dualistas y ocasionalistas de la filosofía moderna. Aunque quizás sí se le podría atribuir el mérito de constatar la necesidad de idear unas nuevas categorías gnoseológicas para explicar la índole particular del conocimiento

98 «But although we see Suarez articulating necessary connection between sense and mind in term of causal harmony which seems a particular instance of the Cartesian or Leibnizian «harmonie pré-établie» (to which God appeals in order to govern the world) [...]». G. Burlando, "Suarez on Intrinsic Representationalism», en Intellect and Imagination in Medieval Philosophy. Actes du Xle Congrès International de Philosophie Médiévale, Brepols Publishers, Turnhout, 2006, p. 1949.

99 «The occasional and non-causal character of Suarez's sense-dependency clearly anticipated Descartes' theory of the origin of perceptual ideas». Spruit, L., Species Intelligibilis (II), p. 385. "Moreover, it would pave the way for Descartes' well-known account of the origin of perceptual ideas, generated by the mind on the occurrence of qualified brain patterns». Ibid., 306.

100 "Sed totum hoc, quod est dicere "ad instar", relinquit rem obscuram et inexplicatam, quia in presenti inquirimus, quem concursum vere et proprie habeat phantasma, non ad cuius instar se habeat. Nam esse ad modum materiae vel exemplaris, vel extrahit illud a vera et propria causa materiali et exemplari, vel relinquit vere et proprie intra limites talis causalitatis. Si extrahit, restat explicare, in qua causalitate ponit. Si relinquit, ergo non ad instar, sed vere et proprie materia vel exemplar est». Juan de Santo Tomás, Cursus Philosophicus Thomisticus. Naturalis Philosophiae. In libros III De anima (ed. Reiser), Marietti, Romae, 1948, IV Pars, q. 10, a. 2, p. 308 a 4-19. 
humano. El pensamiento no es un hecho «natural» más, y por tanto las categorías prestadas de la causalidad del mundo físico resultarán impropias o inadecuadas, aunque reflejan algo de la peculiaridad del conocer ${ }^{101}$. Suárez, todavía hoy, nos ayuda a seguir pensando críticamente sobre la realidad ${ }^{102}$.

Facultad Eclesiástica de Filosofía

José Ángel García Cuadrado

Universidad de Navarra

España.

[artículo aprobado para publicación en noviembre de 2014]

101 Que el conocimiento no tiene propiamente causa no ha dejado de ser sostenido en la actualidad: «El conocimiento, propiamente, no tiene causas». Inciarte, F.-Llano, A., Metafísica tras el final de la metafísica, Cristiandad, Madrid. 2007, p. 55; «Lo único no totalmente explicable por causas físicas es el conocimiento [...] no es explicable por causas naturales la capacidad de formar conceptos». Ibíd. p. 313.

102 Schmutz, J., "¿Abatir o ensalzar a Francisco Suárez»; Prefacio a Francisco Suarez: Der ist der Mann. Homenaje a Salvador Castellote, Facultad de Teologia San Vicente Ferrer, Valencia, 2004, pp. 5-16. 
